\title{
A Study of the Survival Of Specialized Leasing Companies in Sri Lanka
}

\author{
By \\ Nihal Sarath Kumara Weerapana
}

(GS/ MC / 2377 /2004)

Thesis submitted to the University of Sri Jayewardenepura for the Award of the Degree of Maters of Science in Management on $31^{\text {st }}$ December 2007 


\section{Declaration Statement}

The work described in this thesis was carried out by me under the supervision of Dr. Sampath Amaratunge (Head of Business Economics, Faculty of Management Studies \& Commerce, University of Sri Jayewardenepura) and a report on this has not been submitted in whole or in part to any university or any other institution for another Degree/ Diploma.

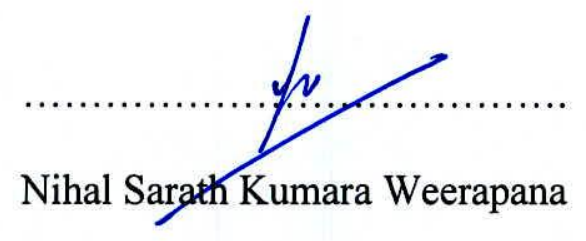

(GS/MC/ 2377 /2004) 


\section{Supervisors Declaration Statement}

I certify that the statement made by the candidate is true and that this thesis has been accepted by the Faculty of Graduate Studies of University of Sri Jayawardenapura after the evaluation .

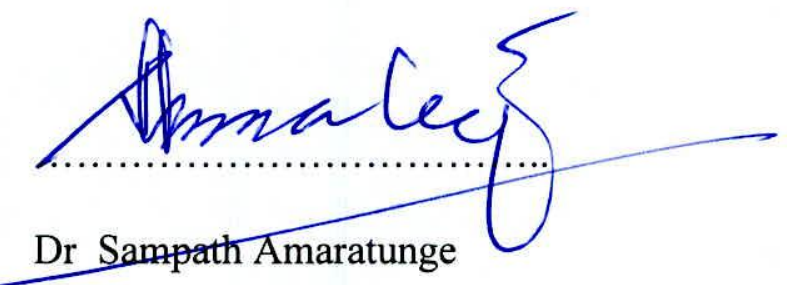

Thesis Supervisor

Dean of Faculty of Management Studies \& Commerce

University of Sri Jayewardenepura

Gangodawila

Nugegoda 


\section{Table of Contents}

Declaration Statement iii

Supervisors Declaration Statement $\quad$ iv

Table of Content $\quad v$

List of Tables $\quad$ xiii

List of Figures $\quad$ xiv

List of Appendices $\quad$ XV

Abbreviations $\quad x$ vi

Acknowledgement xvii

$\begin{array}{ll}\text { Abstract } & \text { xviii }\end{array}$

Chapter One 1

Introduction $\quad 1$

1.1 Background of the Study 1

$\begin{array}{ll}1.2 \text { Significance of the Study } & 11\end{array}$

1.3 Research Problem of the Study 15

$\begin{array}{ll}1.4 \text { Research Objective of the Study } & 18\end{array}$

$\begin{array}{ll}1.5 \text { Limitations of the Study } & 19\end{array}$

1.6 Structure of the Study 19

$\begin{array}{ll}\text { Chapter Two } & 21\end{array}$

$\begin{array}{ll}\text { Review of Literature } & 21\end{array}$

$\begin{array}{ll}2.1 \text { Introduction } & 21\end{array}$

2.2 Reasons to Leasing to Grow 22 
2.3 Impact on Leasing Industry Due to Implementing Basel II

2.4 Opportunities to Develop the Leasing Industry 32

2.5 Impact from Default, Loss and Interest Rate to Leasing Industry 40

2.6 Establishing of Leasing Industry in Azerbajan with the Assistance of ADB 46

2.7 Market Oriented Strategies to Improve the Leasing Industry 48

2.8 New Product Development 53

2.9 Technological Advancement will Develop the Leasing Industry 55

2.10 New Market Developments $\quad 56$

2.11 Customer Satisfaction will lead to Profitability 59

$\begin{array}{ll}\text { Chapter Three } & 65\end{array}$

$\begin{array}{ll}\text { Conceptualization } & 65\end{array}$

$\begin{array}{ll}3.1 \text { Introduction } & 65\end{array}$

$\begin{array}{ll}3.2 \text { Conceptual Frame Work } & 67\end{array}$

$\begin{array}{ll}\text { 3.2.1 Regulator } & 67\end{array}$

$\begin{array}{ll}\text { 3.2.2 Legal Aspects } & 67\end{array}$

$\begin{array}{ll}\text { 3.2.3 Tax Aspects } & 68\end{array}$

3.2.4 Financial Accounting $\quad 69$

3.3 Relationship of Conceptual Frame Work to other Chapters of the Study $\quad 70$

$\begin{array}{ll}\text { Chapter Four } & 71\end{array}$

$\begin{array}{ll}\text { Methodology } & 71\end{array}$

$\begin{array}{ll}4.1 \text { Introduction } & 71\end{array}$

4.2 Background of Leasing Industry 71

$\begin{array}{ll}\text { 4.3 Developing Hypothesis } & 73\end{array}$ 
4.4. Data Collection Methodology 75

$\begin{array}{ll}\text { 4.5 Obtaining of Primary Data } & 75\end{array}$

$\begin{array}{ll}\text { 4.6 Obtaining of Secondary Data } & 78\end{array}$

4.7 References Made to Develop Questionnaires $\quad 79$

$\begin{array}{ll}\text { 4.8 Development of Questionnaire } & 79\end{array}$

$\begin{array}{lr}4.9 \text { Pilot Study } & 80\end{array}$

4.10 Data Collection $\quad 82$

4.11 The Response Rate $\quad 82$

4.12 Data Processing and Analysis $\quad 83$

$\begin{array}{ll}\text { Chapter Five } & 86\end{array}$

$\begin{array}{lr}\text { Analysis } & 86\end{array}$

$\begin{array}{ll}5.1 \text { Introduction } & 86\end{array}$

$\begin{array}{ll}5.2 & \text { Background Information of Customers }\end{array}$

$\begin{array}{ll}\text { 5.2.1 Basic Details } & 87\end{array}$

5.2.2 Other Facilities Enjoyed by Customers 89

$\begin{array}{ll}\text { 5.2.3 Staff Strength } & 90\end{array}$

$\begin{array}{ll}\text { 5.2.4 Stability of Client } & 90\end{array}$

5.2.5 Experience on The Leasing Industry 91

5.2.6 Basic Requirements to be in Business 91

5.2.6.I Operating of Bank Account 91

5.2.6.II Tax Payments 92

5.3 Clients Preference In Obtaining Facilities 92

5.3.1Preference on Facilitators 93 
5.3.2 Features of Bank Facility 94

$\begin{array}{ll}\text { 5.3.3 Why Prefer Loans } & 95\end{array}$

5.3.3.I Preference of Bank Loans 95

5.3.3.II Types of Bank Loans 96

5.3.4 Comparison of Product Offerings of SLC \& RFC 97

$\begin{array}{lll}\text { 5.3.4.I Key Features of SLC } & 97\end{array}$

$\begin{array}{ll}\text { 5.34.II Key Features of RFC } & 97\end{array}$

5.3.5 Comparison of Leasing With Loans 98

5.3.5.1 Convenient Product ( Lease vs. Loans ) 98

5.3.5.II Why Prefer Lease 99

5.3.5.III High Initial Cost $\quad 99$

$\begin{array}{ll}\text { 5.3.5.IV Types of Costs } & 100\end{array}$

5.4 Basic Performance In Leasing Product from Customer Point of View 100

$\begin{array}{ll}\text { 5.4.1 Basic Aspects of Facility } & 100\end{array}$

$\begin{array}{lr}\text { 5.4.1.I Facility } & 100\end{array}$

$\begin{array}{ll}\text { 5.4.1.II Period } & 101\end{array}$

5.4.1.III Monthly Rental 101

$\begin{array}{ll}\text { 5.4.1.IV Pre payments } & 102\end{array}$

$\begin{array}{ll}\text { 5.4.2 Servicing of Contract and Reasons for Default } & 102\end{array}$

$\begin{array}{ll}\text { 5.4.2.I Rental Convenient } & 103\end{array}$

$\begin{array}{lr}\text { 5.4.2.II Difficulties } & 103\end{array}$

$\begin{array}{ll}\text { 5.4.3 Interest Rates Offered on Facilities } & 104\end{array}$

5.4.3.1 Best Mode of Promoting of Leasing Product 105 
$\begin{array}{ll}\text { 5.5 Analysis of Performance of Contracts } & 106\end{array}$

$\begin{array}{ll}\text { 5.5.1 Performance } & 106\end{array}$

$\begin{array}{ll}\text { 5.5.1.I Performance Level of Contracts } & 106\end{array}$

$\begin{array}{ll}\text { 5.5.1.II Default Level } & 106\end{array}$

$\begin{array}{ll}\text { 5.5.2 Handling of Default Clients } & 107\end{array}$

$\begin{array}{ll}\text { 5.5.3 Consequences Face By Default Customers } & 108\end{array}$

$\begin{array}{lr}\text { 5.5.3.I Termination } & 108\end{array}$

5.5.3.II (CRIB) - Credit Information Bureau 109

$\begin{array}{lr}\text { 5.5.3.III Aware of Consequences } & 109\end{array}$

$\begin{array}{ll}\text { 5.5.3.IV Decision of Repossession } & 109\end{array}$

$\begin{array}{ll}\text { 5.5.4 Preference in Litigation } & 110\end{array}$

$\begin{array}{ll}\text { 5.5.5 Customer Opinion on Services Provided } & 111\end{array}$

$\begin{array}{ll}\text { 5.5.5.1 Overall Service } & 111\end{array}$

$\begin{array}{ll}\text { 5.5.5.II Handling of Disasters } & 111\end{array}$

$\begin{array}{ll}\text { 5.5.6 Reputation on Organization } & 112\end{array}$

5.6 Background Information of Managers 112

$\begin{array}{ll}\text { 5.6.1 Basic Details of Mangers } & 112\end{array}$

5.6.2 Knowledge of Leasing Act \& Consumer Credit Act 114

$\begin{array}{ll}\text { 5.6.2.1 Awareness of Leasing Act } & 114\end{array}$

5.6.2.II Leasing act Vs Consumer Credit Act (Favorable to Facilitator ) 115

5.7 Customer Preference and Contribution to Economy 115

$\begin{array}{ll}\text { 5.7.1 Customer Preference } & 116\end{array}$

$\begin{array}{ll}\text { 5.7.1.I Why Prefer Leasing } & 116\end{array}$ 
$\begin{array}{ll}\text { 5.7.1.III Why Prefer Hire Purchase(HP) } & 117\end{array}$

$\begin{array}{ll}\text { 5.7.2 Contribution to Economy } & 118\end{array}$

$\begin{array}{ll}\text { 5.8 Methods of Funding } & 118\end{array}$

$\begin{array}{ll}\text { 5.8.1 Types of Funding } & 119\end{array}$

$\begin{array}{ll}\text { 5.8.1.I Funding through Deposits } & 119\end{array}$

$\begin{array}{lr}\text { 5.8.1.II Funding through Securitization } & 120\end{array}$

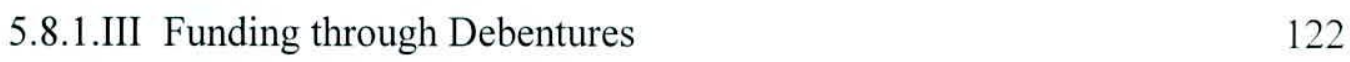

$\begin{array}{lr}\text { 5.8.1.IV Funding through Rights Issues } & 122\end{array}$

$\begin{array}{ll}\text { 5.8.1.V Funding through Term Loans } & 122\end{array}$

$\begin{array}{ll}\text { 5.8.1.VI Funding through ALL the Methods Given Above } & 123\end{array}$

5.9 Comparison of Lending Rates and Deposit Rates with Performance 124

$\begin{array}{ll}\text { 5.9.1 Deposit Rates 2002-2007 } & 124\end{array}$

$\begin{array}{ll}\text { 5.9.1.I Deposit Rates } 2002 & 124\end{array}$

$\begin{array}{ll}\text { 5.9.1.II Deposit Rates } 2003 & 124\end{array}$

$\begin{array}{ll}\text { 5.9.1.III Deposit Rates } 2005 & 124\end{array}$

$\begin{array}{ll}\text { 5.9.1.IV Deposit Rates } 2006 & 125\end{array}$

$\begin{array}{ll}\text { 5.9.1.V Deposit Rates } 2007 & 125\end{array}$

$\begin{array}{lr}\text { 5.9.1.VI Current lending Rates } & 126\end{array}$

$\begin{array}{ll}\text { 5.9.2 NPA and Collection Rates } & 127\end{array}$

$\begin{array}{ll}\text { 5.9.2.I NPA Level of Facilitators } & 127\end{array}$

$\begin{array}{ll}\text { 5.9.2.II Recovery Ratio of Facilitators } & 128\end{array}$

$\begin{array}{ll}\text { 5.9.3 Impact on Vat on Leasing Industry } & 129\end{array}$ 
5.11.1.V Pawning 138

5.11.1.VI Real Estate 138

$\begin{array}{ll}\text { 5.11.1.VII Factoring } & 139\end{array}$

$\begin{array}{ll}\text { 5.11.1.VIII Hiring } & 139\end{array}$

5.11.1.IX Deposits 139

5.11.2 Opinion on Mergers and Acquisitions 140

5.11.3 Analysis of Financial Products with High Returns 140 
5.11.3.I Invest on Hire purchase (HP)

5.11.3.II Invest on Loans

5.11.3.III Invest on Pawning

5.11.3.IV Invest on Real Estate

5.11.3.V Invest on Factoring

5.11.3.VI Invest on Hiring

5.11.3.VII Invest on Leasing

5.11.4 Reaching The Ideal Situation on Services

5.11.5 Returns from Main Resources

5.11.6 Does Organisation Offer Innovative Products

5.11.6.I Innovative Product -Leasing

5.11.6.II Innovative Product - Hiring

5.11.6.III Innovative Product - Leases with Zero Prepayments

5.11.6.IV Innovative Product - Loans

5.11.6.V Innovative Product - Leases without Contribution

5.11.6.VI Innovative Product - HP with Low Contribution

5.11.6.VII Innovative Product - other Features

5.11.7 Industry Cycle

Conclusions and Summary

Reference List 


\section{List of Tables}

Table 2.1 Balancing of Lease Value, High Risk and Loss

Table 5.1 Key Features of Lease Facilities Granted by SLC

Table 5.2 Reasons for Default

Table 5.3 Comparison of Interest Rates offered by Banks and SLC

Table 5.4 Categorizing of default level

Table 5.5 Customer Preference on Leasing

Table 5.6 Customer Preference on Loans

Table 5.7 Customer Preference on Hire purchase

Table5.8 Impact on VAT on Leasing Industry

Table5.9 Impact on Cost of Funds to Profitability

Table5.10 Impact on Cost of Funds to EPS\&ROE

Table5.11 Impact on Cost of Funds to Bad debts

Table 5.12 Growth rates of leasing industry 


\section{List of Figures}

Figure 1.1 The Six Phases of the Leasing Cycle 8

$\begin{array}{ll}\text { Figure 3.1 Conceptual Frame Work } & 66\end{array}$

Figure 5.1 Features of Loans $\quad 94$

$\begin{array}{ll}\text { Figure 5.2 Lending Rates } & 104\end{array}$

$\begin{array}{ll}\text { Figure 5.3 Funding through Deposits } & 119\end{array}$

$\begin{array}{lr}\text { Figure 5.4 Funding through Securitizations } & 120\end{array}$

$\begin{array}{ll}\text { Figure 5.5 Funding through Debentures } & 121\end{array}$

$\begin{array}{lr}\text { Figure 5.6 Funding through Rights Issue } & 122\end{array}$

$\begin{array}{ll}\text { Figure 5.7 Funding through Term Loans } & 122\end{array}$

$\begin{array}{lll}\text { Figure 5.8 Funding through All of Above } & 123\end{array}$

$\begin{array}{ll}\text { Figure 5.9 Deposits } 2006 & 125\end{array}$

$\begin{array}{ll}\text { Figure 5.10 Deposits } 2007 & 125\end{array}$

$\begin{array}{ll}\text { Figure 5.11 Lending Rates } & 126\end{array}$

$\begin{array}{ll}\text { Figure 5.12 NPA Level and Collection Rates } & 127\end{array}$

$\begin{array}{lr}\text { Figure 5.13 Recovery Ratio of Facilitators } & 128\end{array}$

$\begin{array}{ll}\text { Figure 5.14 Impact on Cost of Funds to Segments } & 132\end{array}$

$\begin{array}{ll}\text { Figure } 5.15 \text { Growth rate of leasing industry } & 148\end{array}$ 


\section{List of Appendices}

Appendix 01

Appendix 02

Appendix 03

Questionnaire Developed on Existing Customers Of SLC

Appendix 04

Questionnaire Developed on Managers of SLC

Appendix 05

Analysis of Questionnaire

Appendix 06

Format of Interview Paper - Director of Central Bank (Non Bank Supervision Dept) 218

Appendix 07

Format of Interview Paper of CEO'S of Specialized Leasing Companies

Appendix 08

Funding Methods of Specialised Leasing Companies

Appendix 09

Financial details and Product details of Facilitators 


\section{Abbreviations}

\section{Abbreviation}

SLC

RFC

LCB

LSB

Facilitator

ADB

WB

CB

Lessor

Lessee

GDP

SME

$\mathrm{COF}$

CEO

AWPLR

MFOS

NPV

IFC

NPA / NPL

IMF

NFP

BFI

UK

EPS

ROE

ARB

$\mathrm{D} / \mathrm{C}$

$\mathrm{CHC}$
Definition

Specialized Leasing Company

Registered Finance Company

Licensed Commercial Bank

Licensed Savings Bank

Lending Institution

Asian Development Bank

Word Bank

Central Bank of Sri Lanka

Lending Institution Granting Facility

Customer Obtaining Facility

Gross Domestic Product

Small and Medium Enterprises

Cost of Funds

Chief Executive Officer

Average Prime Lending Rate

Micro Financing Organizations

Net Present Value

International Financial Corporation

Non performing Asset

International Monetary Fund

Non Financial Performance

Bank Financial Institution

United Kingdom

Earnings per Share

Return On Equity

Arbitration

District Courts

Commercial High Courts 


\section{Acknowledgement}

This Study was a success due to the assistance of a large number of individuals who extend their unstinted support and encouragement .

I wish to place on record my sincere gratitude and thanks to Dr Sampath Amaratunge, Head of Department of Business Economics of University of Sri Jayewardenepura , the Supervisor of the Study for his words of wisdom, personal guidance and human inspiration extended to me during the study for which I have no verbal expressions.

I also extend my sincere gratitude and thanks to Mrs Sunethrani Amaratunge Lecturer of University of Kelaniya for her support and encouragement.

Furthermore, I take this opportunity to thank all my lecturers, staff of the Management Faculty, staff of the Library of University of Sri Jayawardenepura, for their assistance and cooperation given to me throughout my degree program .

I also thank the management and staff of Commercial Leasing Company Ltd for providing me the opportunity and every possible assistance for this Study.

Finally my deepest gratitude and sincerest thanks to my wife and family members for the encouragement given to me in this Study . 


\title{
A Study of the Survival of Specialized Leasing Companies in Sri Lanka
}

\section{Nihal S. K. Weerapana}

\begin{abstract}
Leasing industry in Sri Lanka commenced its operation during 1977 under the open economic policy. Initially the industry consist of three specialized leasing companies . The demand for leasing as a medium term source of finance was increased with the economic development of the country. Today 76 lending institutions have registered with Central Bank to offer the same product to establish, medium and small scale customers.
\end{abstract}

The lending institutions in the leasing industry are belongs to four categories such as specialized leasing companies(SLC), registered finance companies(RFC), licensed commercial banks (LCB) and licensed saving banks (LSB). There are 20 SLC'S in the market on competition with finance companies, savings banks and commercial banks in the industry. These four types of institutions are having different levels of resources to carry out business. The competition is increasing in the leasing industry due to the demand for the product. The specialized leasing companies are lacking with the main resource of funding. These SLC are facing a problem of surviving in the industry and the objective of this study is to analyze the factors affecting the survival of SLC . 
The leasing industry will depend on four pillars such as regulator, legal aspects, tax aspects and financial accounting \& depreciation policy. The cost of funds of said 76 lending Institutions are at different levels and competing with each other to hold their market share. The demand for leasing product is increasing since the product reduce capital expenditure of any organization / individual and preserve credit lines available for other purposes . Leasing offer 100\% finance without considering the asset value and also product reduce the effect of inflation because of fixed rentals . The methodology that used in the study are survey based study to gather information from customers and managers through questionnaires and interview based study to get the views of regulator of the industry, Director of non bank supervision of Central Bank of Sri Lanka and two Chief Executive Officers of SLC'S. The cross sectional study has been done on various layers of parties involved in the industry such as customers ,managers, Chief Executive Officers, and Director of non bank supervision of Central Bank of Sri Lanka to find the factors such as depreciation policy of leasing product, amendment to the leasing act, cost of funds of SLC, NPA level, profitability, EPS and ,ROE have an impact on survival of SLC'S. 